\title{
Effect of oral administration of Pleuroteus tuber-regium extract on growth, serum metabolites and histomorphological changes in growing rabbits
}

Suliat Adebola Salami ( $\nabla$ salami.suliata@pg.funaab.edu.ng )

National Biotechnology Development Agency https://orcid.org/0000-0001-6928-9787

Adekunle Babajide Rowaiye

National Biotechnology Development Agency

Samuel Keniokpo Ogoina

Bioresource Development Centre Isanlu

Anyuabuuga Ayuba Amos

bioresource development centre isanlu

Solomon Oluwasunmibare Oni

Bioresource development centre isanlu

Titilayo Mercy Asala

National Biotechnology Development Agency

Bidemi Benson Jayeoba

Bioresource Development Centre Odi

doofan bur

National Biotechnology Development Agency

\section{Research Article}

Keywords: Mushroom extract, serum analytes, intestinal morphology, pathology indicator

Posted Date: April 16th, 2021

DOI: https://doi.org/10.21203/rs.3.rs-306169/v1

License: (c) (i) This work is licensed under a Creative Commons Attribution 4.0 International License. Read Full License 


\section{Abstract}

The effects of oral administration of aqueous extract of Pleuroteus tuber-regium sclerotium (PTRSE) in drinking water on growth, serum analytes and histomorphology parameters were examined using 72 cross bred growing rabbits. Eighteen rabbits each were allotted to 4 treatments with; 0, 500, 750 and $1250 \mathrm{mg}$ PTRSE per liter (mg/l) in drinking water per day. The experiment lasted for 60 days. Data collected were subjected to one-way analysis of variance (ANOVA). The results revealed an improvement in the live weight $(P<0.01)$, weight gain (Linear $(L)$, Quadratic (Q): $P<0.01)$, feed conversion ratio $(L, Q: P<0.01)$, water intake $(L, Q: P<0.01)$ and extract intake $(L$, $\mathrm{Q}: \mathrm{P}<0.01)$ following increasing levels of PTRSE in drinking water. Oral application of $750 \mathrm{mg} / \mathrm{l}$ PTRSE in drinking water resulted in reduced $(P<0.01)$ serum total cholesterol, low-density lipoprotein, very low-density lipoprotein, creatinine and alkaline phosphatase and increased cecal villi height $(L, Q: P<0.05)$ and apical width $(Q: P<0.05)$. Pathological indicators suggested damages to hepatic tissues in rabbits on $1250 \mathrm{mg} / \mathrm{PTRSE}$. In conclusion, the oral application of $750 \mathrm{mg} / \mathrm{P}$ PTRE in drinking water can improve the growth, cholesterol profile and absorptive capacity in growing rabbits without imposing any detrimental effect.

\section{Introduction}

In West Africa, Pleurotus tuber-regium (PTR) is a mushroom specie of high economic value. It is in demands for culinary, medicinal and bioremediation purposes (Oyetayo 2011). Of all the parts of PTR, greater interest is placed on the sclerotium amongst the indigenous people. Researches (Huang et al. 2014; Nworu et al. 2014, Oghenemaro 2017) has shown that PTR sclerotium has hematinic, immunostimulant, anticancer, antiinflammatory, hypolipidemic, hepatoprotective and antihyperglycemic properties Research has also proven its ability to promote the growth of beneficial bacteria, inhibit the proliferation of harmful microbes, enhance immunity and stimulate the growth and proliferation of the absorptive cells in the gut (Sethiya 2016).

The nutraceutical and growth promoting potential of PTR has been largely attributed to its phytochemical constituents and significant amount of non-starch polysaccharides (e.g $\beta$-glucan) found in its cell wall. Solvent extraction of raw plants is usually done to optimize the concentration of bioactive components (Aziz et al. 2003). However, researches have shown that the bioactivities of extract vary according to extraction methods used (Hayouni et al. 2007; Asif and Kaleem 2018). Many bioactive compounds have been identified in mushroom extracts and are available for use as dietary supplements (Jyotika et al. 2013). Hence this study was designed to investigate the effect of the aqueous extract of Pleuroteus tuber-regium sclerotium (PTRSE) and its effects on growth and some physiological and biochemical parameters in growing rabbits.

\section{Materials And Methods}

\section{Pleuroteus tuber-regium extract preparation}

Indigenous edible Nigerian Pleurotus tuber-regium was sourced from the Bioresources Development Centre Isanlu, Kogi State, Nigeria. The sclerotia's dark brown skin was removed while the white tissue was cut into small pieces and pulverized $(>0.5 \mathrm{~mm})$ with a dry electric mill. An aqueous decoction of PTRSE was prepared according to the method described by Poonam et al. (2011). The PTR powder (PTRSP) was added into the water at a ratio of 1:15 w/v. The solution was allowed to cool and then filtered. The filtrate was concentrated and dried in a rotary evaporator maintained at $45^{\circ} \mathrm{C}$ and stored in air-tight containers at room temperature. 


\section{Phytochemical screening of PTRSP and PTRSE}

Samples of PTRSP and freshly prepared PTRSE were collected and screened for phytochemical constituents. Quantitative estimation of the total phenol was determined by the Folin - Ciocalteau reagent method as described by Malick and Singh (1980). Flavonoid concentration was determined and expressed as $\mathrm{mg}$ of rutin equivalent (Helmja et al. 2007). Alkaloid concentration was determined according to the procedure described by Harbone (1984). The tannin contents were determined using Folin Denis Reagent as described by Makkar et al. (1993).

\section{Experimental animals and experimental design}

This experiment was carried out at the Animal House of the Bioresources Development Centre, Isanlu, Kogi State, Nigeria. The rabbits were housed individually in separate hutches measuring $60 \mathrm{~cm} \times 45 \mathrm{~cm} \times 45 \mathrm{~cm}$ under controlled light cycle ( $12 \mathrm{~h}$ light/ $12 \mathrm{~h}$ dark). After a 7-day acclimatization period, 72 cross-bred rabbits with a weight range of 715 and $725 \mathrm{~g}$ were allotted on a weight equalization basis to 4 treatment groups. Eighteen rabbits each were allotted to 4 treatment groups; with 0, 500, 750 and $1250 \mathrm{mg}$ PTRSE per liter (mg/l) in drinking water per day. The extract concentration used in the current study were based on the reports of Okolo et al. (2017) who established that no mortality or toxic signs occurred in Sprague Dawley rats orally administered 50$5000 \mathrm{mg} \mathrm{kg}-1$ b.w of Pleuroteus tuber regium. The required amount of concentrated PTRSE was measured and reconstituted in appropriate volume. Fresh reconstituted drinking water was offered in a pottery on a daily basis to the rabbits. Throughout the 60-day experimental period, the animals were maintained on concentrate ration, formulated to meet the nutrient requirement of growing rabbits (Table 1)

\section{Data collection}

Data was collected on feed intake per pen daily, weight monitored weekly, and mortality records kept. The leftover water was measured the next morning to determine the water and extract intake.

\section{Blood Collection and Serum Chemistry analyses}

On day 60 of the experiment, blood was collected from the ear and/or lateral saphenous veins of 9 rabbits per treatment (36 rabbits in all) for serum biochemical analyses. The activities of alkaline phosphatase (ALP), total protein, albumin, total cholesterol, triglycerides high-density lipoprotein (HDL), low-density lipoprotein (LDL), verylow-density lipoprotein (VLDL) and aspartate aminotransferase (AST), alanine aminotransferase (ALT), creatinine and blood urea nitrogen (BUN) were determined according to the methods described by Reitman and Frankel (1957). Commercial laboratory test kits (Randox laboratories UK) and a UV Vis Spectrophotometer (721 (D), PEC Medical, USA) was used to carry out these analyses.

\section{Histomorphological parameters}

On the $60^{\text {th }}$ day of the experiment, a total of 24 rabbits comprising 6 rabbits per treatment, were slaughtered after their weights were taken. The heart, stomach, kidney, spleen, and liver of the rabbits were harvested and weighed. The percentage weights of the harvested organs relative to the carcass were determined. Small pieces of the caecum, duodenum and liver tissues were collected in $10 \%$ formalin buffer for proper fixation. The tissues were embedded in paraffin wax, histological sections of 5-6 $\mu \mathrm{m}$ in thickness were made and stained with hematoxylin and eosin for gut measurements and histopathological examinations 


\section{Statistical analysis}

Data collected were subjected to a one-way analysis of variance (ANOVA) test in a completely randomized design. Statistical analysis was carried out using the 9.1 version of the SAS software (SAS, 2000). A Duncan, multiple range test was done at $95 \%$ confidence interval to separate statistically significant means. Polynomial contrast (Linear (L), quadratic (Q) and cubic (C)) was also applied to determine the effect of dosage of PTRSE.

\section{Results}

Figure 1 shows the concentration of phytochemicals present in both PTRS powder and extract. Phytochemicals with antioxidant properties were detected in varying concentrations in both PTRSP and PTRSE. The phytate, tannin, alkaloid and phenol contents of the extract were higher than those of the powder. However, the flavonoid content of the extract was lower than that of the powder. Cyanide, an important antinutrient was also detected in minute amounts in in both powder and extract.

Table 2 shows the performance and serum biochemical parameters in the experimental rabbits. The live weight $(P<0.01)$ and weight gain $(L, Q: P<0.01)$ increased following increasing levels of extract in drinking water. In a similar vein, $F C R$ reduced $(L, Q: P<0.01)$. The highest values for live weight and weight gain were recorded in rabbits administered $750 \mathrm{mg} / \mathrm{I}$ PTRSE while the least values were seen in the control group. Feed intake and FCR in rabbits on $750 \mathrm{mg} / \mathrm{l}$ were similar to those on $1250 \mathrm{mg} / \mathrm{l}$ PTRSE.A corresponding decline in feed intake (L:P< $0.05, Q: P<0.01)$. followed increasing levels of PTRS extract in drinking water. Water intake $(P<0.05)$ in rabbits on $500 \mathrm{mg} / \mathrm{l}$ and $750 \mathrm{mg} / \mathrm{I}$ PTRSE were higher than those of the control group. As the extract's levels in drinking water increased, extract intake increased $(L, Q: P<0.01)$. Percentage mortality in all treatments were less than $5 \%$.

In comparison with the control and other treatment groups, serum albumin concentration was cubically lower ( $P$ $<0.05)$ while globulin was higher $(\mathrm{L}: \mathrm{P}<0.05, \mathrm{Q}: \mathrm{P}<0.01)$ in rabbits on $750 \mathrm{mg} / \mathrm{PTRSE}$. Serum total cholesterol in rabbits administered varying levels of extract in drinking water was higher $((L: P<0.05, Q: P<0.01)$, Triglyceride was quadratically lower $(P<0.05), H D L$ and $L D L$ were higher $(P<0.01)$ while VLDL was quadratically lower $(P<$ $0.05)$ than those of the control group. An increase $(L: P<0.05, Q: P<0.01)$ in glucose concentration was observed following increasing levels of extract in drinking water and rabbits on $1250 \mathrm{mg} / \mathrm{I}$ PTRSE had the highest value while the control group had the least. Serum creatinine in rabbits on varying levels of PTRSE was cubically lower $(P<0.05)$ than those of the control and rabbits on $750 \mathrm{mg} / \mathrm{I}$ PTRSE had the lowest value. Serum ALT was quadratically lower $(P<0.01)$ in rabbits on $500 \mathrm{mg} / \mathrm{l}$ while ALP was lowest $(L, Q: P<0.01)$ in rabbits on $750 \mathrm{mg} / \mathrm{l}$ PTRSE when compared to those of control and other treatment groups.

Table 3 shows the relative organ weights and intestinal measurements in growing rabbits orally administered with aqueous extracts of PTRS in drinking water. The relative weight of kidney and cecum were cubically higher $(P<0.01)$ in T2 while those of small intestine were cubically lower $(P<0.01)$ in $T 3$ when compared with the control and those allotted to other treatment groups. There were no differences $(P>0.05)$ in the relative weights of liver, spleen, heart, stomach and duodenum. Cecal weight in rabbits on $750 \mathrm{mg} / \mathrm{I}$ PTRSE was cubically higher $(P<0.01)$ than those on other treatment groups. Cecal villi height in rabbits on 750 and $1250 \mathrm{mg} / \mathrm{l}$ PTRSE was higher $(L, Q: P<0.05)$ while apical width in rabbits on $750 \mathrm{mg} / \mathrm{I}$ PTRSE was quadratically higher $(P<0.05)$ than those of the control group. A non-significant $(P>0.05)$ increase in duodenal villi height was also observed following increasing levels of extracts in drinking water. 
Pathology indicators suggest the worst liver tissue damage occurred in rabbits on $1250 \mathrm{mg} / \mathrm{l}$ (Fig. 5). and the least occurred in those on $750 \mathrm{mg} /$ PTRSE (Fig. 3). The histopathological evaluation of the hepatic tissue samples was based on the pattern and severity of the injury. The experimental rabbits showed signs of nonalcoholic fatty liver disease (NAFLD) as seen with the different degrees of micro vesicular steatosis observed in rabbits on 0, 500 and $750 \mathrm{mg} / \mathrm{I}$ PTRSE (Fig. 2-5). There are no necrotic zones, necroinflammation, cholestatic patterns of liver injury in all the groups. However, a focal area of hemorrhagic lesion was seen in rabbits on 1250 mg/l PTRSE (Fig. 5).

\section{Discussion}

Higher phytochemical contents found in PTRSE in comparison to PTRSP is an indication that hot water extraction resulted in the optimization of the concentrations of these bioactive compounds. This in line with the reports of Jo et al. (2012). Lower flavonoid content in PTRSE is an indication that hot water extraction may have led to the degradation of this phytochemical. This observation agrees with the reports of Elhamirad and Zamanipoor (2012) who found that many antioxidants exhibiting high preventive activity at storage temperatures, rapidly break down and lose their effectiveness when exposed to elevated temperatures. Therefore, for optimization of flavonoid extraction, other formal extraction methods that do not involve elevated temperature should be explored. Antinutrients (tannin, cyanide and phytate) detected in both powder and extract occurred at minimal dose considered to be non- toxic to the rabbits.

The improved growth found in rabbits on PTRSE compared to control agrees with the report of Guo et al. (2004) who showed that mushroom extract increases body weight gain and lowers FCR in broilers. Decline in feed intake amongst rabbits administered PTRSE suggest that PTRSE is an appetite suppressant in agreement with the result of Hess et al. (2017) who found that mushroom extract increased satiety and reduced prospective food intake in human subjects. The opposite trend in water intake against declining FCR seen in rabbits on PTRSE is similar to the observations of Chikumba, and Chimonyo (2014) in chickens. Percentage mortality in all rabbits were less than $5 \%$ and increases in hepatic enzymes were not reflected. This indicates that PTRSE (up to $1250 \mathrm{mg} / \mathrm{l}$ ) do not impose detrimental effects on the rabbits. This observation is in sync with the reports of Okolo et al (2017) in rats orally administered $50-5000 \mathrm{mg} \mathrm{kg-1} \mathrm{b.w} \mathrm{of} \mathrm{Pleuroteus} \mathrm{tuber} \mathrm{regium.}$

Improved cholesterol metabolism seen in rabbits administered PTRSE contrasts with the results of ljeh et al. (2009). The author found that dietary incorporation of PTR at 5 and $10 \%$ had no significant hypolipidaemic effects in albino mice. These differences in observations may be due to differences in the mode and route of administering the PTRSE. In the former study PTRSP was incorporated into diet while extract was added to water in the current study. This observation suggest that the extraction of the whole plant and the route of administration (via drinking water) led to the release of more bioavailable phytochemicals, consequently improving cholesterol metabolism. Reduced serum enzyme concentration on PTRSE administration to rabbits suggests that increasing levels of extract in drinking water did not cause any injury to the growing rabbit's tissue. Most values were not higher than those of the control and were within the range previously reported for normal rabbits (1.78-9.8 mmol/I for AST, 1.4-16.6 mmol/I for creatinine, 0-10.0 IU/I for ALT, and 4-20 IU/I for ALP (Harcourt-brown 2002;; Archetti et al. 2008). These results suggests that the dosage of PTRSE used in the current study is not harmful to the liver. 
Relative weight in most of the visceral organs among rabbits on varying levels of PTRSE and control suggest there was no hepatic injury and this corresponds with the liver enzymes result earlier reported in the current study. The highest cecal weight in rabbits on $750 \mathrm{mg} /$ I PTRSE is an indicator of improved feed motility and digestibility (Hulls et al., 2012). Increasing values of villi height and apical width observed in this study indicate that increasing levels of PTRSE in drinking water of growing rabbits enhances the intestinal absorptive surface and this corresponds to greater absorption of available nutrients and improved growth (Yasar and Forbes 1999; Panda, et al. 2015)

The different degrees of micro-vesicular steatosis seen in experimental rabbits are likely caused by obesity and that caged animals lack sufficient exercise. Over time, NAFLD has the propensity to culminate in Non-alcoholic steatohepatitis (NASH) and chronic hepatitis characterized by cellular, congestion, and fibrosis. group might be suggestive of vascular injury. The focal area of haemorrhagic lesion seen in rabbits on $1250 \mathrm{mg} / \mathrm{IPTRSE}$ is a sign of Drug-induced liver injury (DILI) but further investigation is required since the level of hepatic enzymes does not suggest so (Kleiner 2017).

It was concluded that the oral administration of $750 \mathrm{mg}$ of the aqueous extract of Pleuroteus tuber-regium per litre of drinking water can improve the growth, cholesterol profile and nutrient absorptive capacity of growing rabbits without imposing any detrimental effect.

\section{Declarations}

Acknowledgements: The authors are grateful for the support of the Management of Bioresources Development Centre, Isanlu, Kogi State Nigeria for providing the resources needed for this research work.

\section{Author's contributions}

SA, AB, SO, TM conceived and designed research.

SA, SK, AA, BB and D conducted experiments.

TM and SO contributed new reagents or analytical tools.

SA analyzed data.

SA, AB, SO and TM wrote the manuscript.

All authors read and approved the manuscript.

Funding: Not applicable

Conflicts of interest/Competing interests: The authors have no conflict of interest to declare

Availability of data and material (data transparency): Not applicable

Code availability: Not applicable

Ethics approval: All procedures performed in this study were done following the institution's ethical standards or practice at which the studies were conducted. The experiment was performed in accordance with the ethical 
standards laid down in the 1964 Declaration of Helsinki and its later amendments.

Consent to participate: Not applicable

Consent for publication: All authors have given their consent for their name to be included in this publication

\section{References}

Archetti, I., Tittarelli, C., Cerioli, M., Brivio, R., Grilli, G. Lavazza, A., 2008. Serum chemistry and hematology values in commercial rabbits: preliminary data from industrial farms in northern Italy. Proceeding of the 9th World Rabbit Congress, Verona, Italy, 1147-1152

Asif, A., Muhammad, K. 2018. $\beta$-Glucan as a Food Ingredient In: Grumezescu A.M and Holban A.M ed Academic press, London, 351-381.

Aziz, R.A., Sarmidi, M.R., Kumaresan, S., 2003. Phytocehemical processing: the next emerging field in chemical engineering aspects and opportunities Jabatan Kejuruteraan Kimia dan Proses, Universitas Kebangsaan,, Malaysia, 45-60

Chikumba, N., Chimonyo, M., 2014. Effects of water restriction on the growth performance, carcass characteristics and organ weights of naked neck and ovambo chickens of southern Africa. Asian-Australasian Journal of Animal Science, 27(7), 974-980

Elhamirad, A.H., Zamanipoor, M.H., 2012. Thermal stability of some flavonoids and phenolic acids in sheep tallow olein. European Journal of Lipid Science and Technology, 114 (5), 602-606.

Guo, FC., Kwakkel, RP., Williams, BA., Li, WK., Li, HS., Luo, JY., Li, XP., Wei, YX., Yan, ZT., Verstegen, MW., 2004. Effects of mushroom and herb polysaccharides, as alternatives for an antibiotic, on growth performance of broilers. British Poultry Science, 45(5), 684-94.

Harborne, JB., 1984. Methods of Plant Analysis. In: Phytochemical Methods. Springer, Dordrecht.

Harcourt-Brown, F., 2002. The Textbook of Rabbit Medicine, $4^{\text {th }}$ edition, Butterworth Heinemann education, 28-30 Hayouni, M., Abedrabba, M., Bouix, MH., 2007. The effects of solvents and extraction method on the phenolic contents and biological activities in vitro of Tunisian Quercus coccifera L. and Juniperus phoenica L. fruit extracts. Food Chemistry, 105,1126-1134

Helmja, K., Vaher, M., Gorbatsova, J., Kaljurand, M.2007. Characterization of bioactive compounds contained in vegetables of the Solanaceae family by capillary electrophoresis. Proceeding of the Estonian Academy of Science and Chemistry 56, 172-186.

Hess, JM., Qi, WC., Kraft, J., Slavin, L., 2017 Impact of Agaricus bisporus mushroom consumption on satiety and food intake. Appetite, 117(1), 179-185

Huang, HY., Korivi, M., Yang, HT., Huang, CC., Chaing, YY., \& Tsai, YC., 2014. Effect of Pleurotus tuber-regium polysaccharides supplementation on the progression of diabetes complications in obese-diabetic rats. Chinese 
Journal of Physiology, 57 (4), 198-208.

Hulls, C., Lentle, RG., Reynolds, GW. Patrick W., Janssen M., Chambers P., de Loubens, C., 2016. Ex vivo motility in the base of the rabbit caecum and its associated structures: an electrophysiological and spatiotemporal analysis. Journal of Physiology and Biochemistry,72, 45-57.

ljeh, I.I., Okwujiako, I.A., Nwosu, P.C., Nnodim, H.I., 2009. Phytochemical composition of Pleurotus tuber regium and effect of its dietary incorporation on body /organ weights and serum triacylglycerols in albino mice. Journal of Medicinal Plant Research, 3 (11), 939-943.

Jo, I., Kim, S., Min B., Jung, H., Han Y., Kim J., 2017. Optimization of hot-water extraction conditions of bioactive compounds from coffee residue extracts. Korean Journal of Chemical Engineering,55 (3), 358-362

Jyotika, V., Jot, H.O., Bhushan, M.J., Istvan, A., Jenny, F., Rhond, L S., Andrew D. P., Marghereta, T.C., 2013. White button mushrooms increase microbial diversity and accelerate the resolution of Citrobacter rotentium infection in mice. The Journal of nutrition, 143 (4), 526-532

Kleiner, D.E., 2017. Histopathological challenges in suspected drug-induced liver injury. Liver international, 38 (2), 198-209.

Makkar, H.P., Blummel, S.M., Borowy N.K., Becker, K. 1993. Gravimetric determination of tannins and their correlations with chemical and protein precipitation methods. Journal of the Science of Food and Agriculture, 61, 161-165.

Malick, C.P., Singh, M.B., 1980. Plant enzymology and histo-enzymology. $4^{\text {th }}$ ed.Kalyani Publishers, New Delhi, 278

Nworu, C.S., Ihim S.A., Okoye, F.B., Esimone, C.O., Adikwu, M.U., and Akah P.A., 2014. Immunomodulatory and immunorestorative activities of $\beta$-d-glucan-rich extract and polysaccharide fraction of mushroom, Pleurutus tuberregium.. Journal of Pharmaceutical Biology, 53 (11),1555-1566.

Oghenemaro, E.F., 2017. Effect of aqueous and ethanol extracts of Pleurotus tuber regium on the haematological indices of albino wistar rats. Journal of Pharmaceutical Research and Allied Sciences, 14(5)

Okolo, K.O., Orisakwe O.E., Siminialay, I.M., 2017. Pleurotus tuber-regium mushrooms in the diet of rats ameliorates reproductive and testicular injury caused by carbon tetrachloride. Clinical Phytoscience, 3,14-24

Oyetayo, 0., 2011. Medicinal uses of mushrooms in Nigeria: towards full and sustainable exploitation. African Journal of Traditional and Complementary and Alternative Medicine, 8(3), 267-274.

Panda A.K., Bhanja, S.K., Sunder, G., 2015. Early post hatch nutrition on immune system development and function in broiler chickens. World poultry Science Journal, 71 (2), 285-296.

Poonam, G.D., Appasaheb, A., Ghadge, S.B., Tannaz, J.B., 2011. Preparation of decoction of Medicinal Plants: A Self-Help Measure. The Journal of Alternative and Complementary Medicine, 17 (12), 1099-1100. 
Reitman, S., Frankel, S. 1957. A colorimetric method for the determination of serum glutamic oxalacetic and glutamic pyruvic transaminases American Journal of Clinical Pathology, 128 (1),56-63

SAS, 2000. SAS Users Guide ;.. Version 9.1 revised edition, SAS Institute Inc, Carry, NC.

Sethiya, N.K., 2016. Review on natural growth promoters available for improving gut health of poultry: an alternative to antibiotic growth promoters. Asian Journal of Poultry Science, 10,1-29.

Yasar, S., Forbes, J.M., 1999. Performance and gastro-intestinal response of broiler chickens fed on cereal grainbased feeds soaked in water. British Poultry Science, 40, 65-76.

\section{Tables}

Table 1 Ingredient and nutrient composition of the diet

\begin{tabular}{lc}
\hline Items & $(\mathrm{g} / \mathrm{kg})$ \\
\hline Maize offal & 100.0 \\
Maize & 310.0 \\
Full fat Soya & 100.0 \\
Groundnut cake & 50.0 \\
Wheat offal & 300.0 \\
Rice husk & 100.0 \\
Oyster shell & 10.0 \\
Bone meal & 20.0 \\
Premix & 5.0 \\
Salt & 5.0 \\
Total & 1000 \\
Proximate composition (\% Dry matter) & \\
Crude protein & 15.3 \\
Crude fat & 5.14 \\
Crude fibre & 12.47 \\
Calcium & 0.01 \\
\hline
\end{tabular}

Premix composition per $\mathrm{Kg}$ diet: vit A: 4000000IU, vit D: $800000 \mathrm{IU}$, vit E: $40000 \mathrm{mg}$, vit $\mathrm{K}_{3}$ : $800 \mathrm{mg}$, vit $\mathrm{B}_{1}: 1000 \mathrm{mg}$, $6000 \mathrm{mg}$, vit $\mathrm{B}_{6}: 5000 \mathrm{mg}$, vit $\mathrm{B}_{12}: 25 \mathrm{mg}$, Niacin: 6000mg, Panthothenic acid: 2000mg, Folic acid: 200mg, Biotin: 8mg, Man! 300000mg, Iron: 8000mg, Zinc: 20000mg, Cobalt: 80mg, Iodine: 400mg, Selenium: 40mg, Choline: 800000mg.

Table 2 Performance characteristics and serum biochemical measurements in experimental rabbits administered varying levels of PTRSE in drinking water. 


\begin{tabular}{|c|c|c|c|c|c|c|c|c|}
\hline \multirow[b]{2}{*}{ arameter } & \multicolumn{4}{|c|}{$\begin{array}{l}\text { Amount of PTRSE in drinking water in } \\
\mathrm{mg} / \mathrm{l}\end{array}$} & \multicolumn{4}{|c|}{ Probability } \\
\hline & 0 & 500 & 750 & 1250 & SEM & Linear & Quadratic & Cubic \\
\hline itial weight (g/rabbit) & 718.03 & 725.09 & 725.29 & 721.56 & 1.71 & NS & NS & NS \\
\hline inal live weight (g/rabbit) & $1284.33^{\mathrm{d}}$ & $1562.14^{\mathrm{c}}$ & $1810.75^{\mathrm{a}}$ & $1723.16^{\mathrm{b}}$ & 42.55 & $* *$ & NS & $* *$ \\
\hline eight gain (g/rabbit/day) & $9.44^{\mathrm{d}}$ & $13.95^{\mathrm{c}}$ & $18.09^{\mathrm{a}}$ & $16.69^{b}$ & 0.70 & $* *$ & $* *$ & $* *$ \\
\hline əed intake (g/rabbit/day) & $71.17^{\mathrm{a}}$ & $67.08^{a b}$ & $64.00 \mathrm{bc}$ & 61.41 bc & 1.03 & $* *$ & $* *$ & $* *$ \\
\hline eed conversion ratio & $7.54^{\mathrm{a}}$ & $4.81^{\mathrm{b}}$ & $3.54^{\mathrm{c}}$ & $3.68^{\mathrm{c}}$ & 0.342 & $* *$ & $* *$ & $*$ \\
\hline ater intake (ml/rabbit/day) & $157.17^{\mathrm{b}}$ & $193.17^{\mathrm{a}}$ & $183.03^{\mathrm{a}}$ & $150.24^{\mathrm{b}}$ & 4.88 & $* *$ & NS & NS \\
\hline xtract intake (mg/l/rabbit/day) & $0.000^{\mathrm{d}}$ & $0.086^{\mathrm{c}}$ & $0.135^{\mathrm{b}}$ & $0.178^{\mathrm{a}}$ & 0.014 & $* *$ & $* *$ & $* *$ \\
\hline [ortality (\%) & $1.67^{\mathrm{b}}$ & $2.20^{\mathrm{b}}$ & $3.33^{\mathrm{a}}$ & $3.33^{\mathrm{a}}$ & 0.228 & $* *$ & NS & NS \\
\hline otal protein (g/dl) & 9.02 & 9.13 & 8.75 & 9.09 & 0.12 & NS & NS & NS \\
\hline lbumin (g/dl) & $5.47^{\mathrm{a}}$ & $5.34^{\mathrm{a}}$ & $4.51^{\mathrm{b}}$ & $5.72^{\mathrm{a}}$ & 0.14 & NS & NS & $*$ \\
\hline lobulin $(\mathrm{g} / \mathrm{dl})$ & $3.46^{\mathrm{b}}$ & $3.79^{\mathrm{ab}}$ & $4.24^{\mathrm{a}}$ & $3.38^{\mathrm{b}}$ & 0.12 & $*$ & $*$ & $*$ \\
\hline otal cholesterol (mg/dl) & $52.91^{\mathrm{c}}$ & $93.07^{\mathrm{a}}$ & $66.36^{\mathrm{b}}$ & $62.56^{\mathrm{bc}}$ & 3.48 & $* *$ & $*$ & $* *$ \\
\hline riglyceride (mg/dl) & $79.42^{\mathrm{a}}$ & $62.20^{\mathrm{b}}$ & $66.13^{\mathrm{b}}$ & $61.89^{\mathrm{b}}$ & 2.08 & NS & $*$ & $* *$ \\
\hline igh density lipoprotein (mg/dl) & $26.85^{\mathrm{c}}$ & $52.84^{\mathrm{a}}$ & $38.73^{b}$ & $35.11^{b}$ & 2.35 & $* *$ & NS & $* *$ \\
\hline ow density lipoprotein (mg/dl) & $10.18^{\mathrm{c}}$ & $27.79^{\mathrm{a}}$ & $14.40^{\mathrm{b}}$ & $15.07^{\mathrm{b}}$ & 1.41 & $* *$ & $* *$ & $* *$ \\
\hline $\begin{array}{l}\text { ery low density lipoprotein } \\
\mathrm{ng} / \mathrm{dl})\end{array}$ & $15.88^{\mathrm{a}}$ & $12.44^{\mathrm{b}}$ & $13.23^{\mathrm{b}}$ & $12.38^{\mathrm{b}}$ & 0.42 & NS & $*$ & $* *$ \\
\hline lucose $(\mathrm{mg} / \mathrm{dl})$ & $117.36^{\mathrm{b}}$ & $120.20^{\mathrm{b}}$ & $123.7^{\mathrm{b}}$ & $138.40^{\mathrm{a}}$ & 2.09 & $* *$ & $*$ & NS \\
\hline reatinine (mg/dl) & $1.18^{\mathrm{a}}$ & $0.853^{\mathrm{ab}}$ & $0.66^{\mathrm{b}}$ & $1.14^{\mathrm{ab}}$ & 0.09 & NS & $*$ & NS \\
\hline spartate transaminase $(\mathrm{Iu} / \mathrm{L})$ & 52.07 & 51.87 & 50.04 & 51.29 & 0.79 & NS & NS & NS \\
\hline lanine amino transferase $\mathrm{T}(\mathrm{Iu} / \mathrm{L})$ & $49.67^{\mathrm{a}}$ & $37.87^{\mathrm{b}}$ & $44.89^{\mathrm{a}}$ & $44.89^{\mathrm{a}}$ & 1.30 & NS & $* *$ & $*$ \\
\hline lkaline phosphatase (Iu/L) & $73.58^{\mathrm{a}}$ & $68.67^{\mathrm{a}}$ & $58.53^{b}$ & $70.27^{a}$ & 1.79 & $* *$ & $* *$ & $*$ \\
\hline
\end{tabular}

a-d Means along the same row with different superscripts are significantly different at $\mathrm{P}<0.05$ and $\mathrm{P}<0.01$

$* \mathrm{P}<0.05 * * \mathrm{P}<0.01 \quad$ NS not significant

ble 3 Organ relative weights and intestinal histomorphometry measurements in rabbits administered varying evels of $\mathrm{SE}$ in drinking water. 


\begin{tabular}{|c|c|c|c|c|c|c|c|c|}
\hline \multirow[b]{2}{*}{ ter } & \multicolumn{4}{|c|}{ Amount of PTRSE in drinking water in $\mathrm{mg} / \mathrm{l}$} & \multicolumn{4}{|c|}{ Probability } \\
\hline & 0 & 500 & 750 & 1250 & SEM & Linear & Quadratic & Cubic \\
\hline ght (g) & $1163.20^{\mathrm{ab}}$ & $1035.45^{\mathrm{b}}$ & $1254.05^{\mathrm{a}}$ & $1059.45^{b}$ & 32.66 & NS & NS & NS \\
\hline$\%)$ & $0.60^{\mathrm{b}}$ & $0.69^{\mathrm{a}}$ & $0.58^{\mathrm{b}}$ & $0.65^{\mathrm{ab}}$ & 0.02 & NS & NS & $*$ \\
\hline j) & $3.41^{\mathrm{ab}}$ & $3.36^{\mathrm{ab}}$ & $3.76^{\mathrm{a}}$ & $2.51^{\mathrm{b}}$ & 0.19 & NS & NS & NS \\
\hline$\%)$ & 0.04 & 0.04 & 0.04 & 0.05 & 0.002 & NS & NS & NS \\
\hline \%) & 0.25 & 0.25 & 0.27 & 0.25 & 0.007 & NS & NS & NS \\
\hline . $(\%)$ & 2.50 & 3.81 & 2.50 & 2.83 & 0.30 & NS & NS & NS \\
\hline um (\%) & 2.39 & 1.77 & 1.94 & 2.00 & 0.15 & NS & NS & NS \\
\hline testine (\%) & $1.66 \mathrm{a}$ & $0.97^{\mathrm{b}}$ & $2.31^{\mathrm{a}}$ & $1.83^{\mathrm{a}}$ & 0.17 & NS & NS & $* *$ \\
\hline (\%) & $7.82^{\mathrm{bc}}$ & $6.19^{\mathrm{c}}$ & $10.00^{\mathrm{a}}$ & $7.82^{\mathrm{bc}}$ & 0.50 & NS & NS & $* *$ \\
\hline yht $(\mu \mathrm{m})$ & $700.00^{\mathrm{b}}$ & $625.00^{\mathrm{b}}$ & $990.00^{\mathrm{a}}$ & $1100.00^{\mathrm{a}}$ & 61.65 & $* *$ & $*$ & $* *$ \\
\hline ridth $(\mu \mathrm{m})$ & $70.00^{\mathrm{b}}$ & $70.00^{\mathrm{b}}$ & $100.00^{\mathrm{a}}$ & $50.00^{\mathrm{b}}$ & 6.53 & NS & $*$ & $*$ \\
\hline idth $(\mu \mathrm{m})$ & 250.00 & 200.00 & 215.00 & 200.00 & 8.90 & NS & NS & NS \\
\hline propial depth( $\mu \mathrm{m})$ & 50.00 & 40.00 & 40.00 & 40.00 & 2.18 & NS & NS & NS \\
\hline \multicolumn{9}{|l|}{ um } \\
\hline yht $(\mu \mathrm{m})$ & 400.00 & 410.00 & 450.00 & 500.00 & 27.74 & NS & NS & NS \\
\hline ridth $(\mu \mathrm{m})$ & 35.00 & 30.00 & 35.00 & 35.00 & 11.25 & NS & NS & NS \\
\hline idth $(\mu \mathrm{m})$ & 70.00 & 60.00 & 75.00 & 70.00 & 4.09 & NS & NS & NS \\
\hline propial depth $(\mu \mathrm{m})$ & 45.00 & 50.00 & 40.00 & 55.00 & 4.15 & NS & NS & NS \\
\hline
\end{tabular}

a-c Means along the same row with different superscripts are significantly different at $\mathrm{P}<0.05$ and $\mathrm{P}<0.01$ $* \mathrm{P}<0.05 * * \mathrm{P}<0.01 \quad$ NS not significant

\section{Figures}




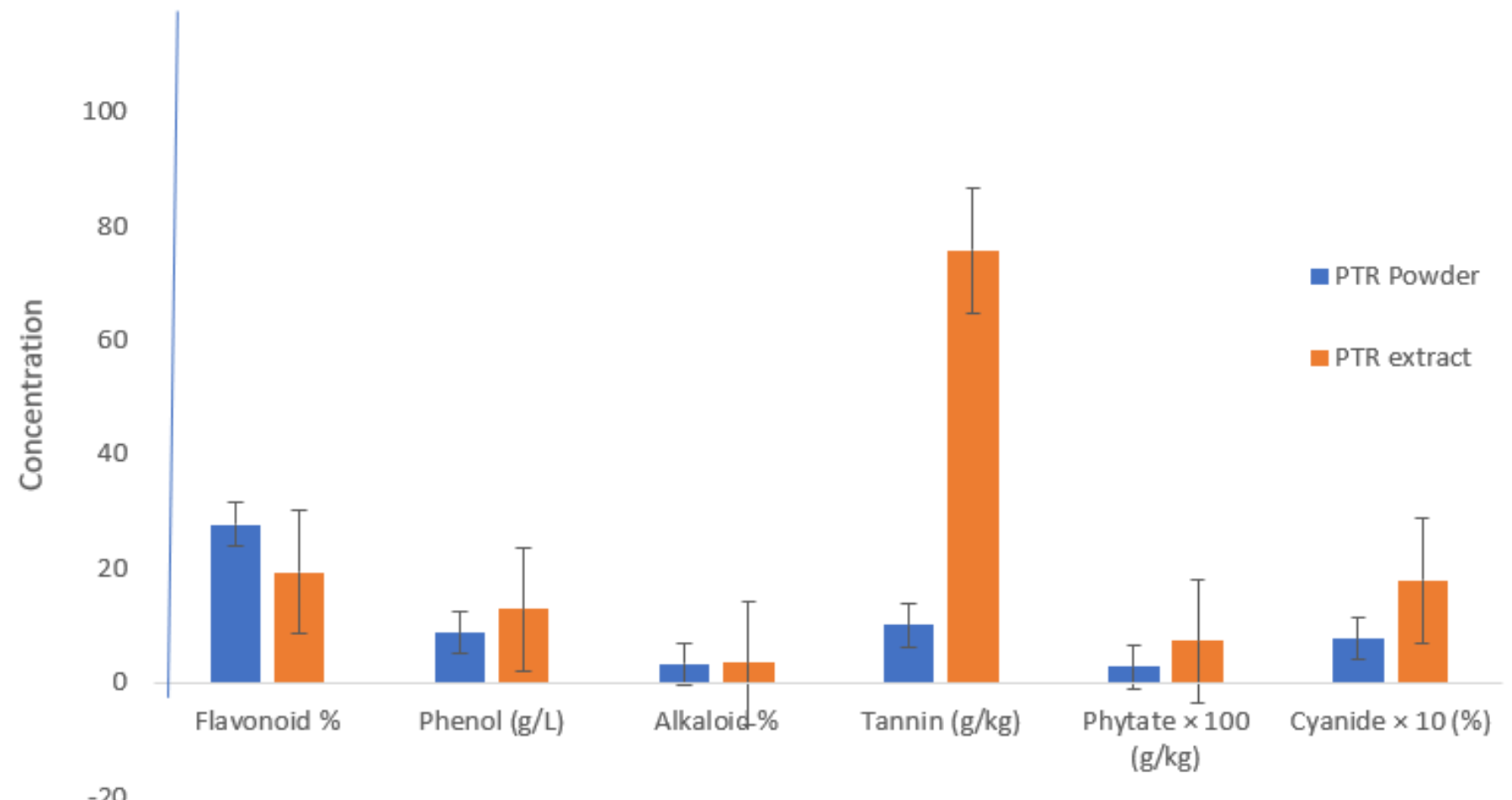

Phytochemical

Figure 1

Quantitative assay of the Phytochemical constituents of PTR powder and extract 


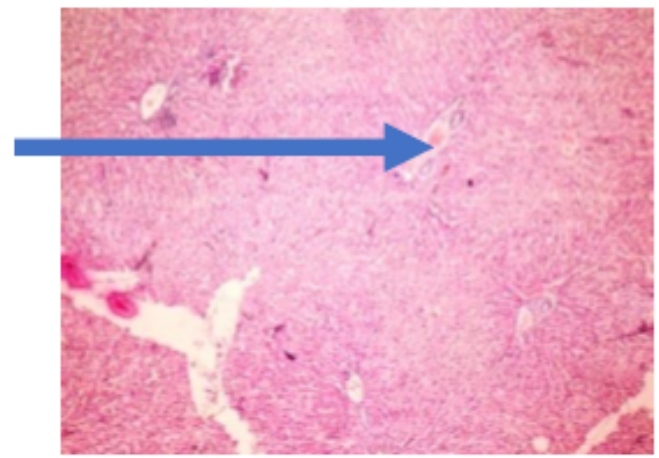

X40

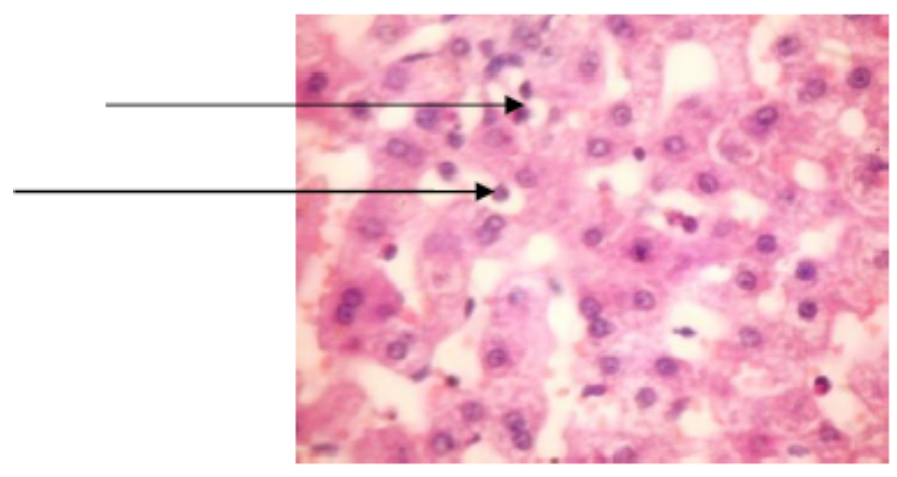

X400

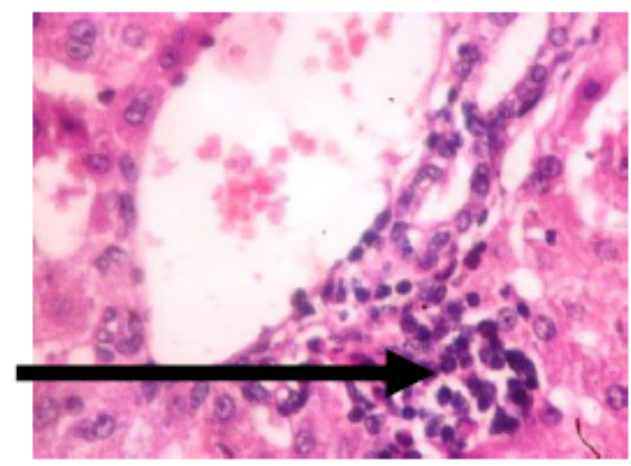

$\mathrm{X} 400$

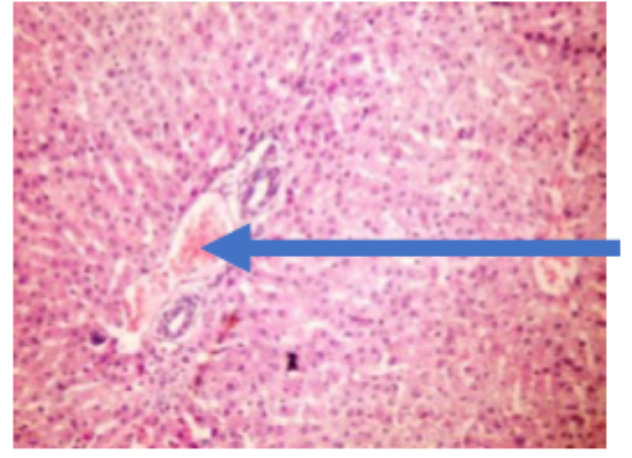

$\mathrm{X} 100$

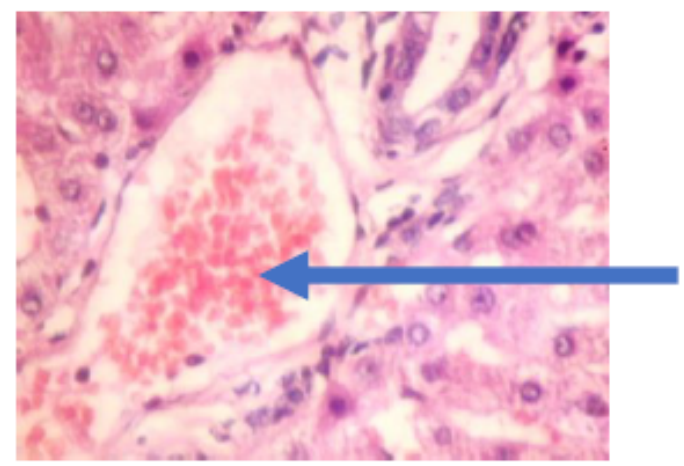

$\mathrm{X} 400$

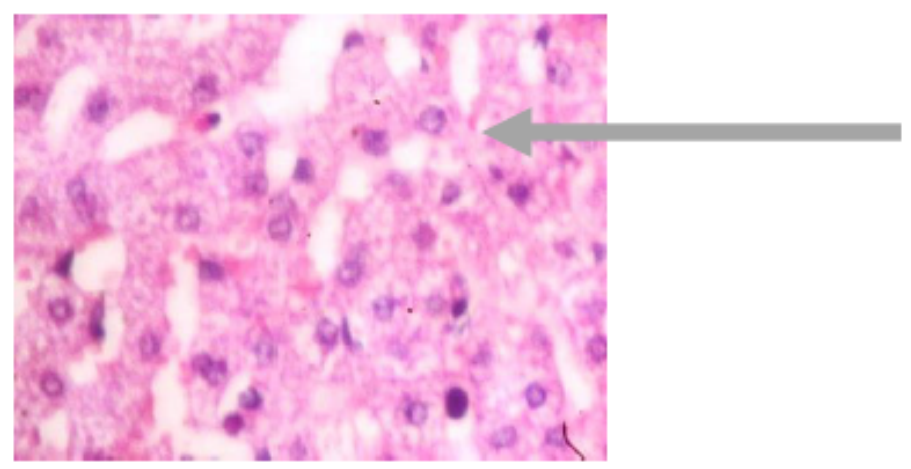

$\mathrm{X} 400$

\section{Figure 2}

Liver plates show mild to moderate disseminated microvesicular steatosis (green arrows), congestion (blue arrows), mild periportal infiltration by inflammatory cells (black arrows) and mild infiltration of zone 2 by inflammatory cells (dotted arrow). 


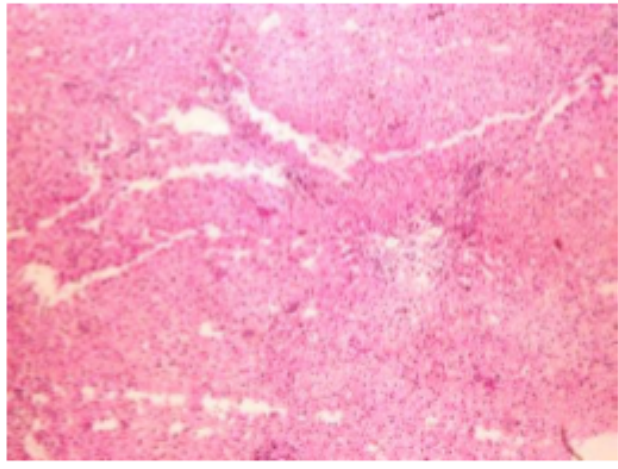

$\mathrm{X} 40$

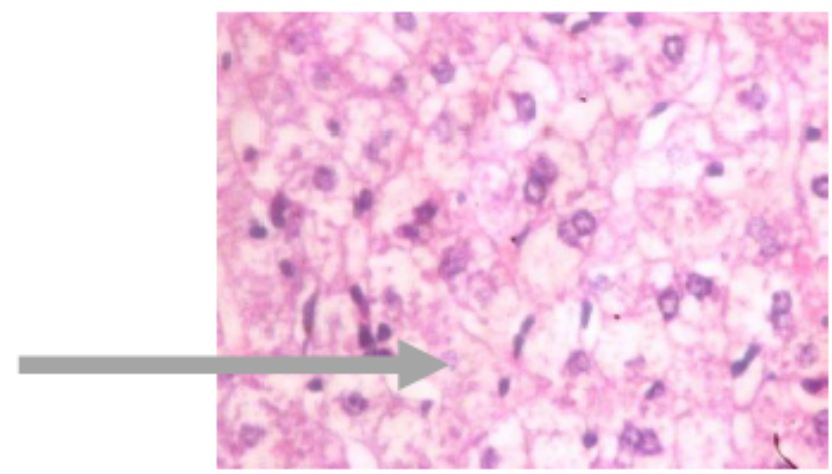

X400

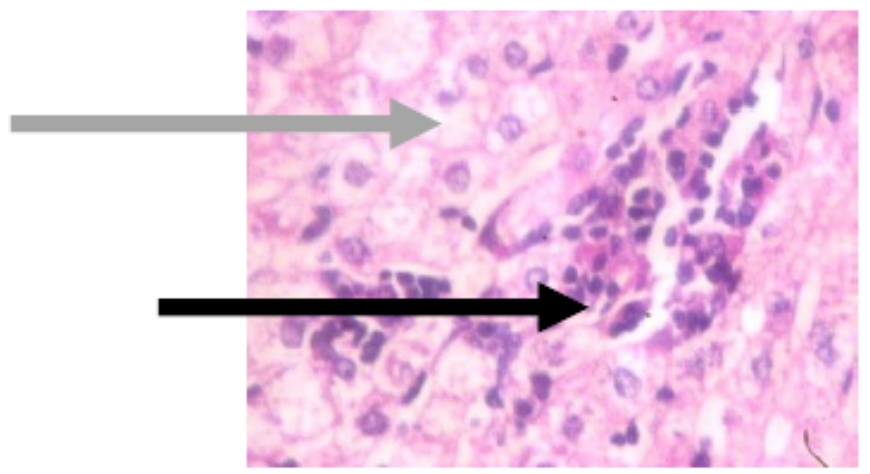

X400

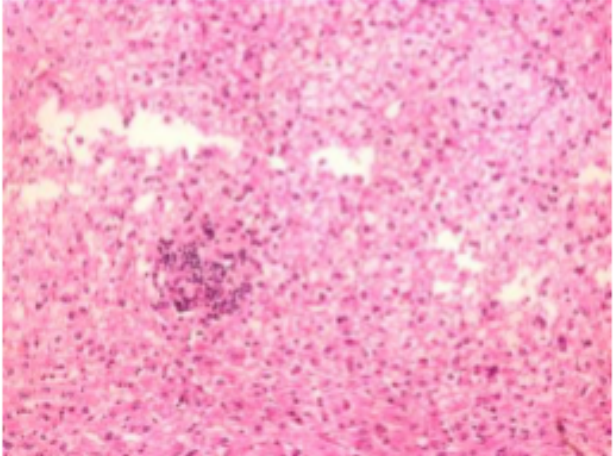

$\mathrm{X} 100$

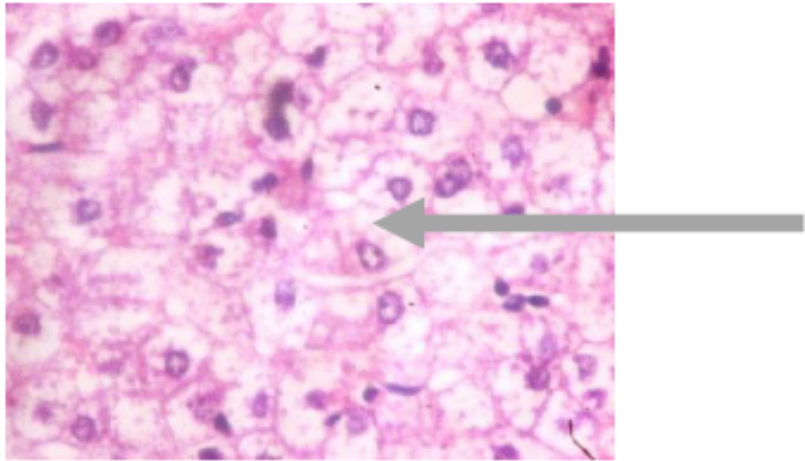

$\mathrm{X} 400$

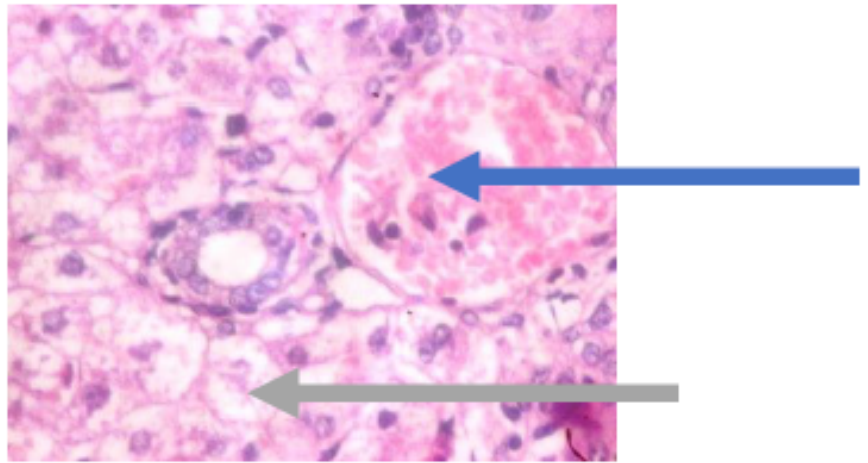

$\mathrm{X} 400$

\section{Figure 3}

Liver plates show marked to severe disseminated microvesicular steatosis (green arrows), mild periportal steatosis (black arrows) and focal congestion (blue arrows). 


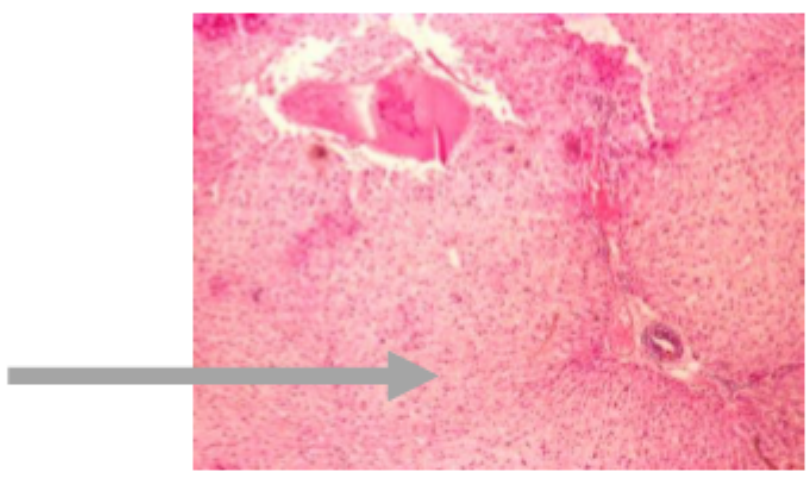

X40

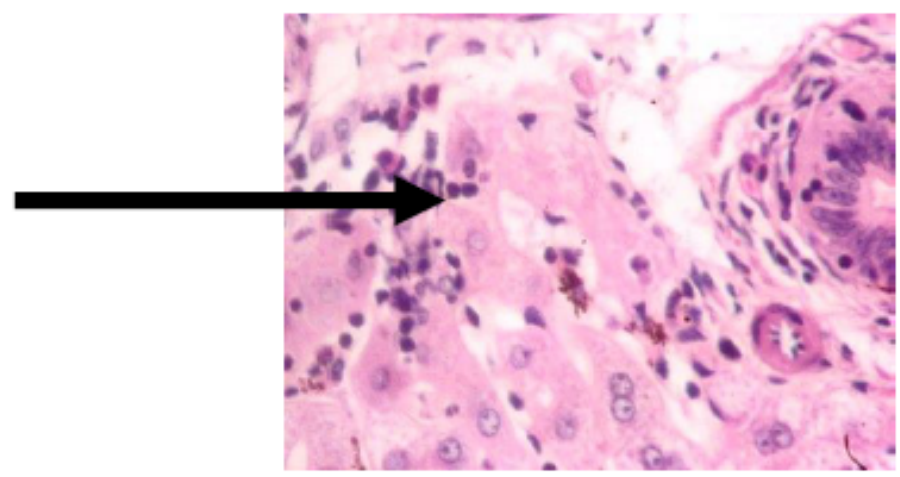

X400

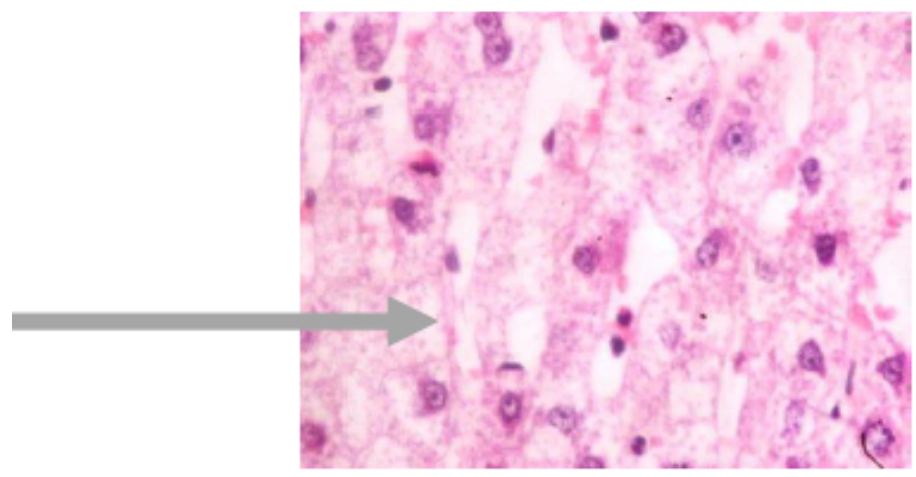

X400

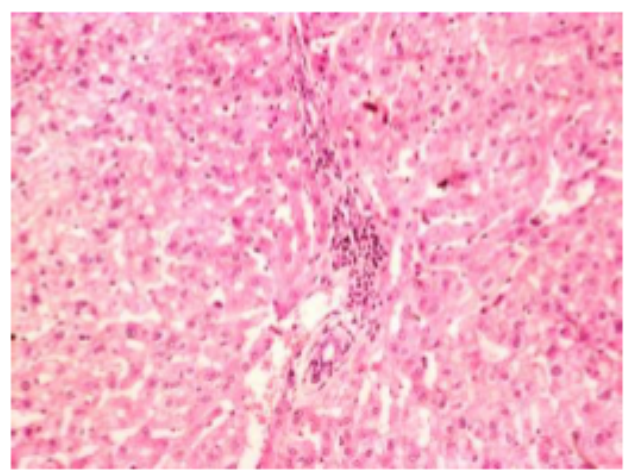

X100

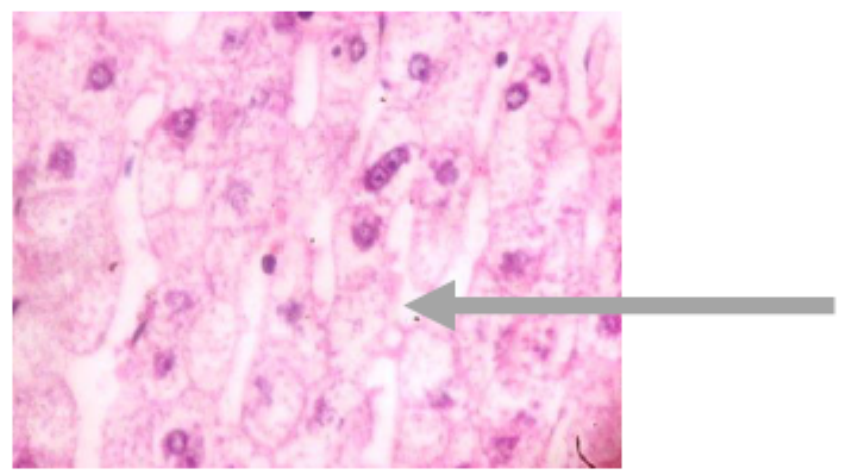

$\mathrm{X} 400$

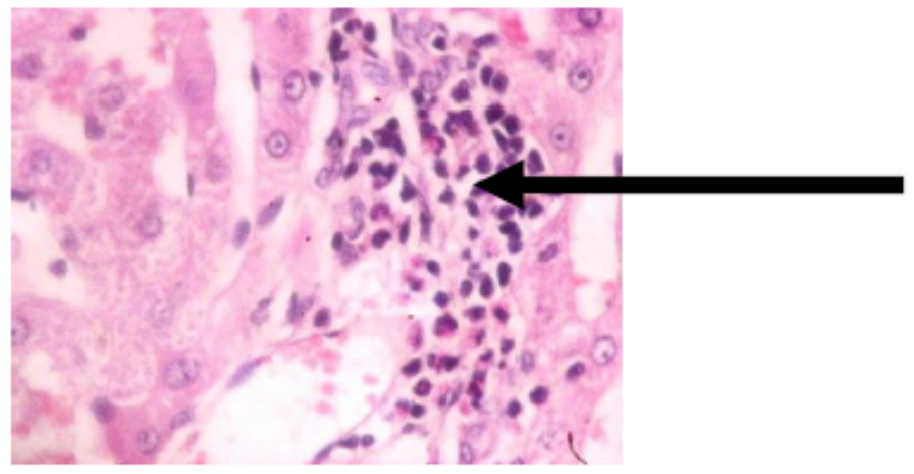

X400

\section{Figure 4}

Liver plates shows moderate to marked disseminated microvesicular steatosis (green arrows) and focal area of periportal infiltration by inflammatory cells (black arrows). 


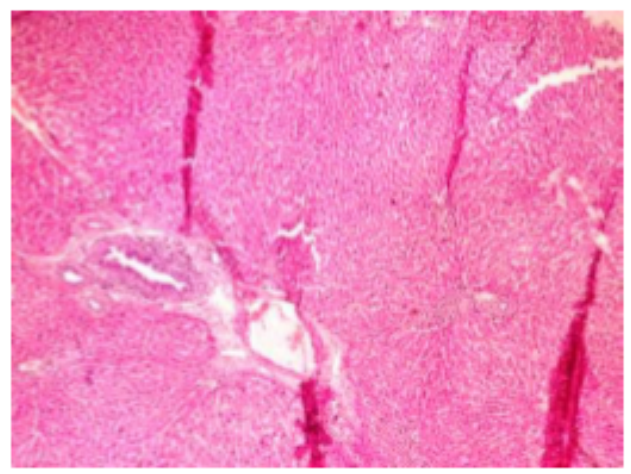

X40

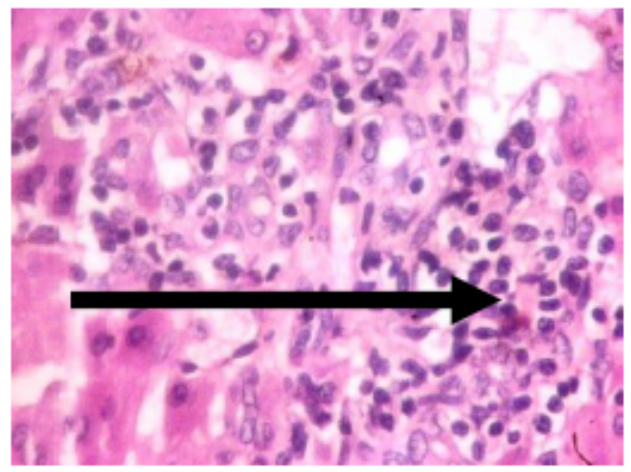

X400

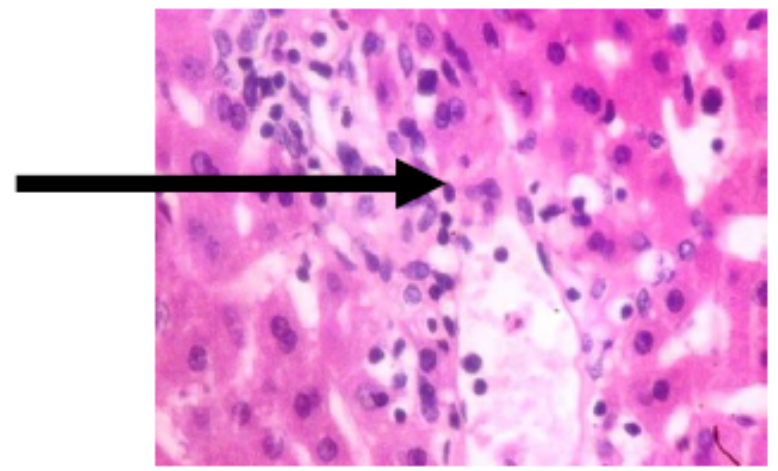

X400

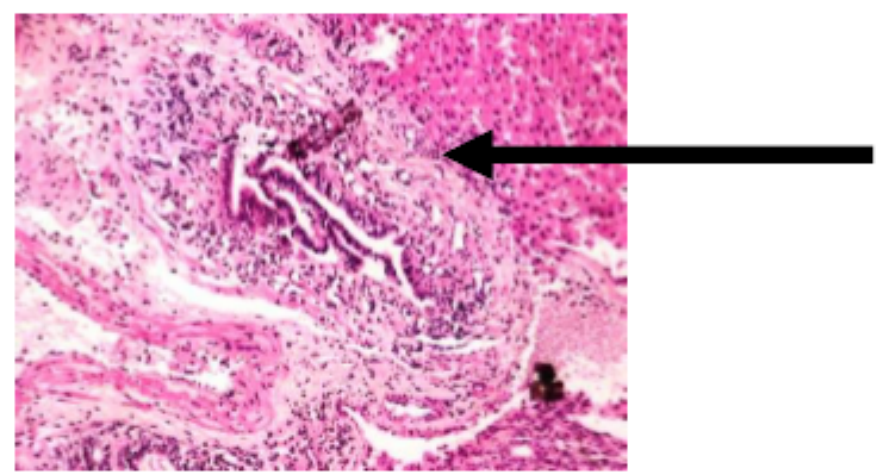

$\mathrm{X} 100$

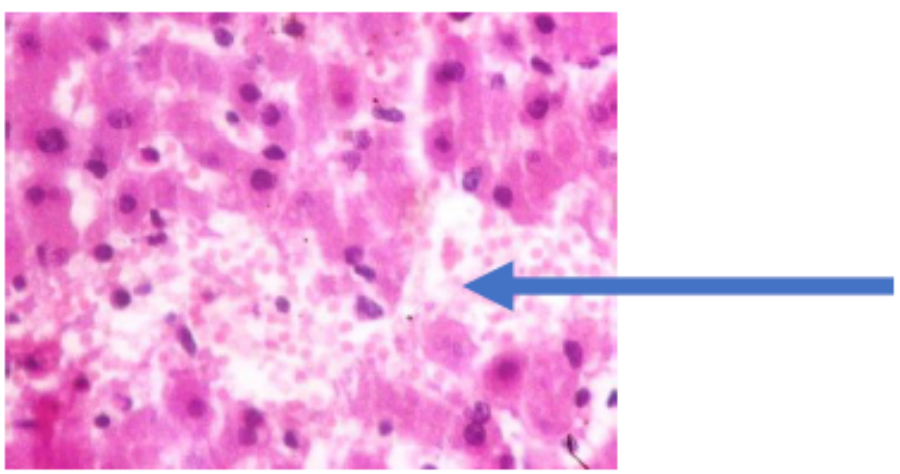

X400

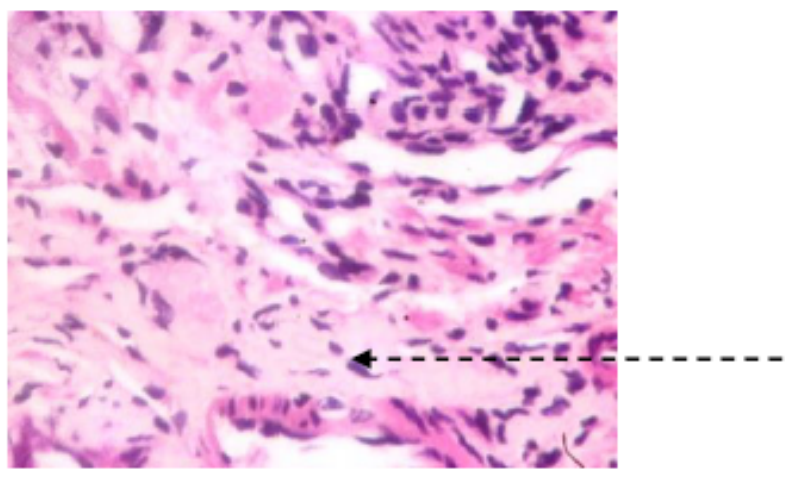

X400

\section{Figure 5}

Liver plates show periportal infiltration by inflammatory cells (black arrows), portal fibrosis (dotted arrow) and focal area of hemorrhagic lesion (blue arrows). 